\title{
Performance of pile foundation for the civil infrastructure of high speed rail in severe ground subsidence area
}

\author{
H. W. Yang \\ Taiwan High Speed Rail Corporation, Taiwan \\ Correspondence to: H. W. Yang (hw_yang@ thsrc.com.tw) \\ Published: 12 November 2015
}

\begin{abstract}
In this study, the performance of pile foundation is assessed for the $30 \mathrm{~km}$ long viaduct bridge structure seating in the ground subsidence area in the central part of Taiwan. The focus of this paper is placed on the settlement behaviour of a continuous 3-span R. C. viaduct bridge supported on piles adjacent to highway embankment. Monitoring data accumulated over the last 12 years indicate that the observed pace of the settlement of the viaduct structure in other sections matches that of the ground. However, the bridge piers adjacent to the embankment have been suffering an additional approximately $1 \mathrm{~cm}$ settlement every year since the completion of the embankment construction. It was believed that the piers may suffer from enormous negative skin friction owing to the surcharge from the embankment and groundwater depression. This paper first summarizes the settlement analysis results to quantify the settlement of pile due to regional ground subsidence and the combined effects from ground water fluctuation and embankment surcharge loading. Accordingly, a loading path on $\mathrm{P}^{\prime}-\mathrm{q}$ stress space is formulated to illustrate the loading variation subject to the combined loading effects that can explain why the combined effect becoming significant on settlement control for civil infrastructure in ground subsidence area.
\end{abstract}

\section{Introduction}

Taiwan, like many other countries, has been suffering from land subsidence problems resulting from the over-extraction of groundwater over the last four decades. Around $30 \mathrm{~km}$ of the Taiwan High Speed Rail (HSR) crosses over the area with the most severe ground subsidence by viaduct bridge seating on pile foundations. Monitoring records have shown that the observed settlements of the viaduct structure match well with those of the ground. However, excluding the regional ground subsidence effect, one continuous 3-span viaduct bridge crossing over a highway embankment has been suffering at least an additional $1 \mathrm{~cm}$ annual settlement since the completion of its embankment construction in 2003.

The bridge in question is a continuous 3-span R.C. viaduct bridge supported on reverse circulation drilled (RCD) piles. It was built in 2002, and shortly after its completion, another earth-filled embankment for a highway was placed underneath its main span. Since 2003, the accumulated settlement of piers adjacent to the highway embankment is $575 \mathrm{~mm}$, and the differential settlements between piers are near $30 \mathrm{~mm}$. The pier settlement is considered attributable to the regional ground subsidence and surcharge effect from embankment. This study aims to quantify the pile settlement behaviours subject to dead load from the viaduct structure, surcharge from the adjacent embankment, seasonal fluctuation of groundwater level, and regional ground subsidence.

\section{Site and structures}

\subsection{Soil and groundwater}

The site is located at the toe of the southern Chuoshui River Alluvial Fan (CRAF). Based on the conceptual hydrogeological model (1), the sediments in CRAF contain unconsolidated sand, gravel, silt, and clay, with a total depth of over $2 \mathrm{~km}$. The aquifers near the head of CRAF mainly contain gravel and coarse sand that become finer towards the toe of CRAF. The aquifers in the toe of the southern CRAF contain highly compressible granular material with loosely scattered clay (Yang et al., 2007). 


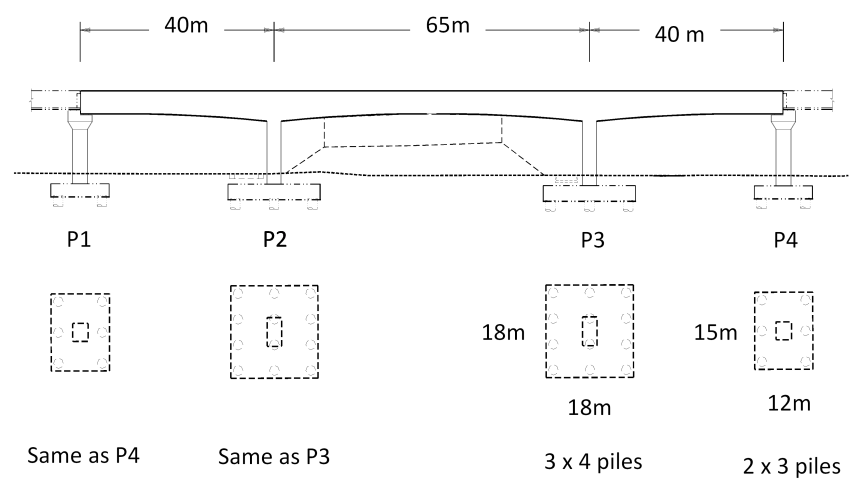

Figure 1. Cross section of viaduct and pile cap plan.

The groundwater table at the site was $2-4 \mathrm{~m}$ below the ground surface. In the sandy layer at $50-160 \mathrm{~m}$ depth, called the "Second Aquifer," a lower piezometric head was observed owing to the over-extraction of groundwater from this aquifer. A higher piezometric head can be seen annually in the wet season from April to November. In the dry season, the groundwater pressure head declines by $\sim 6 \mathrm{~m}$.

\subsection{Viaduct bridge \& earth-filled embankment}

The continuous 3-span viaduct bridge is a " $\pi$ "-shaped structure. The central span of the bridge is $65 \mathrm{~m}$ and the two outer spans are $40 \mathrm{~m}$. The superstructure was constructed using the balanced-cantilever method from the two main piers. The last and center segments of the bridge were completed in April 2002. Each bridge pier is supported by an individual pile group. Figure 1 shows the cross section of the bridge and the plan of the pile groups. RCD piles of $2 \mathrm{~m}$ diameter were used, with pile lengths of $63.5 \mathrm{~m}$ for $\mathrm{P} 2$ and $\mathrm{P} 3$ and a slightly shorter length of $53.4-59.5 \mathrm{~m}$ for $\mathrm{P} 1$ and $\mathrm{P} 4$. The remainder of the viaduct bridge extending from the two end piers P1 and P4 had simple supported beams with piers on similar piles to $62-\mathrm{m}$ depth. All piles at this site are $100 \%$ friction piles supporting only the design load, which is $3427 \mathrm{kN} /$ pile for P2 and P3 and $4562 \mathrm{kN} /$ pile for P1 and P4.

The earth-filled embankment is $6 \pm 0.5 \mathrm{~m}$ high with $53.6 \mathrm{~m}$ width at the bottom, and it has slope angles of $36^{\circ} \pm 2^{\circ}$. The embankment was filled in two stages-first to a height of $2.55 \mathrm{~m}$ from 1998 to 2001 and then to its full height from January 2003 to November 2004. The bridge's pile foundations were constructed during the period between these two stages.

\section{Characteristics of regional ground subsidence near site}

The study site is located in the most severe ground subsidence area in CRAF in Yunlin County. The piezometric head in the aquifers usually drops to its lowest level and gradually rises to the peak in the following rainy season. The cyclic

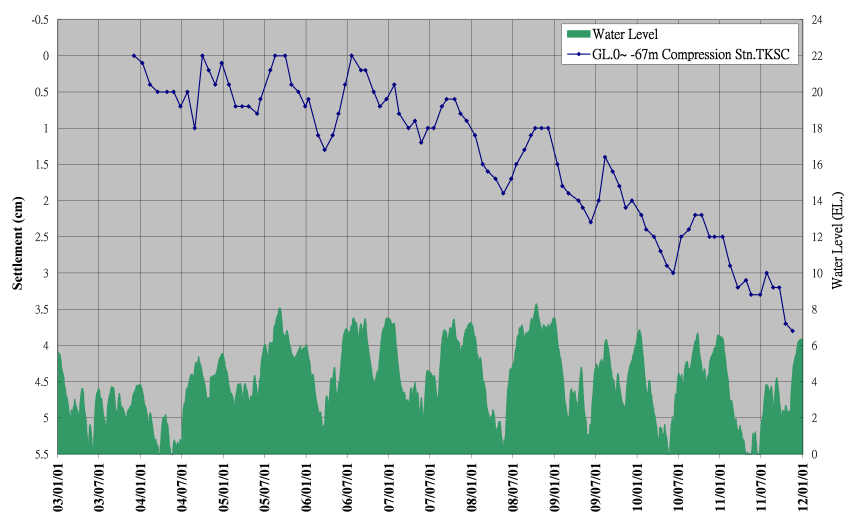

Figure 2. Groundwater level fluctuation and compression of soil.

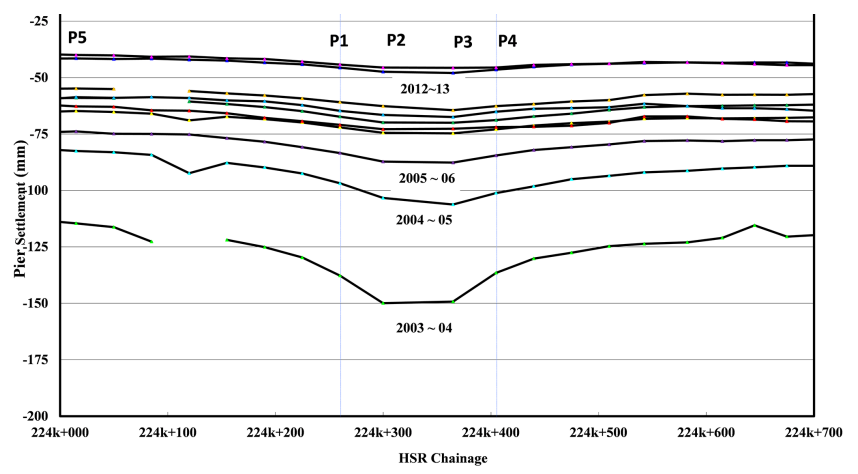

Figure 3. Settlement trough with the center of embankment.

fluctuation of groundwater pressure changes the effective stress and inevitably leads to the compaction of the aquifer and, in turn, land subsidence. In 2003, the Stn. TKSC monitoring station was established by the government included a GPS station, a $300 \mathrm{~m}$-long "sondex" tube type multilevel compaction monitoring well, groundwater monitoring well, and benchmark for leveling survey. Based on the data from Stn. TKSC, Yang (2013) summarized the characteristics of ground subsidence and groundwater variations, particularly within $67.4 \mathrm{~m}$ depth, as follows.

Annual average subsidence of ground below GL.-300 m was rather constant at $25 \mathrm{~mm} \mathrm{yr}^{-1}$.

Total ground surface settlement from 2003 to 2011 was $608 \mathrm{~mm}$, of which 570 and $38 \mathrm{~mm}$ was from soil compression below and above $67.4 \mathrm{~m}$ depth, respectively.

As the groundwater pressure has been dropping progressively in recent years, the total compression of the ground became larger than its total upheaval, resulting in an accumulated compression of $38 \mathrm{~mm}$ in the $0-67.4 \mathrm{~m}$ soil layer from 2003 to 2011. Figure 2 demonstrates the variation of groundwater level and compression of soil layer. 


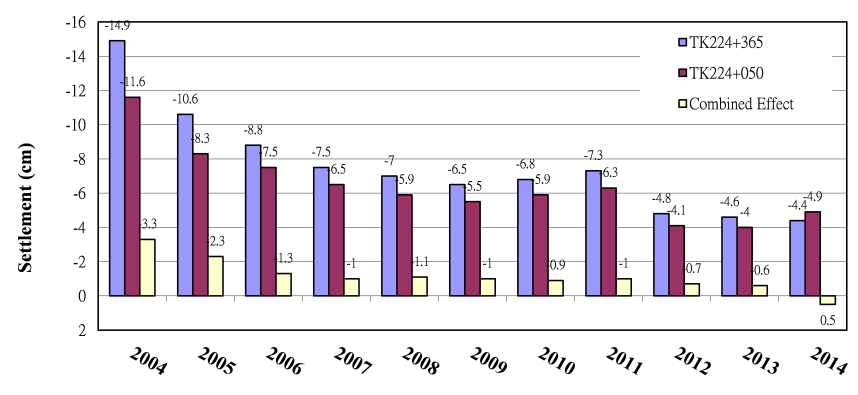

Figure 4. Pile settlment due to combined effect.

\section{Settlement of viaduct bridge}

Starting from October 2003, settlement markers fixed on all piers were monitored annually. These four piers as indicated in Fig. 1 are categorized as the main piers $\mathrm{P} 2$ and P3, which are adjacent to the embankment, and the outer piers P1 and $\mathrm{P} 4$. The settlement rates of the piers at each side of the embankment are plotted in Fig. 3. It is observed that a settlement trough with the center of the embankment has been formed since 2004. Five piers at each side of the embankment are within the area of this settlement trough. These ten piers appear to be affected by the surcharge loading from the embankment. The main piers suffer the highest settlement and simultaneously take the highest surcharge loading from the embankment. The surcharge loading from the embankment could have caused ground compression next to the foundation piles, resulting in downdrag force or negative skin friction acting on the foundation piles.

Two piers, P5 and P3, are selected to comparatively study the pile settlement behaviour. Both piers are located in an area with the same background of ground subsidence. However, P5 is $260 \mathrm{~m}$ distant from P3 and is located outside the settlement trough shown in Fig. 3, which can represent the typical pile foundation subject to the effect of ground subsidence only. The monitoring results of multilevel compaction in the monitoring well at Stn. TKSC represent the natural ground subsidence at various soil depths. Pier P5 settled $707 \mathrm{~mm}$ from 2003 to 2014. A comparison of the ground subsidence below the pile tip level and pier settlement showed that the latter was only $3 \mathrm{~mm}$ larger than the former. Similarly, under the same natural condition but with an additional surcharge load next to P3, P3 settled $132 \mathrm{~mm}$ more than the ground subsidence at pile tip level. Figure 4 shows a comparison of the settlement history of P3 and P5; both piers show similar annual settlement patterns, with larger differences in the first 3 years. Since 2007, a constant deviation rate of $10 \mathrm{~mm} \mathrm{yr}^{-1}$ was observed. The behaviour of $\mathrm{P} 3$ can be attributed to the combined effect of surcharge load and cyclic groundwater lowering
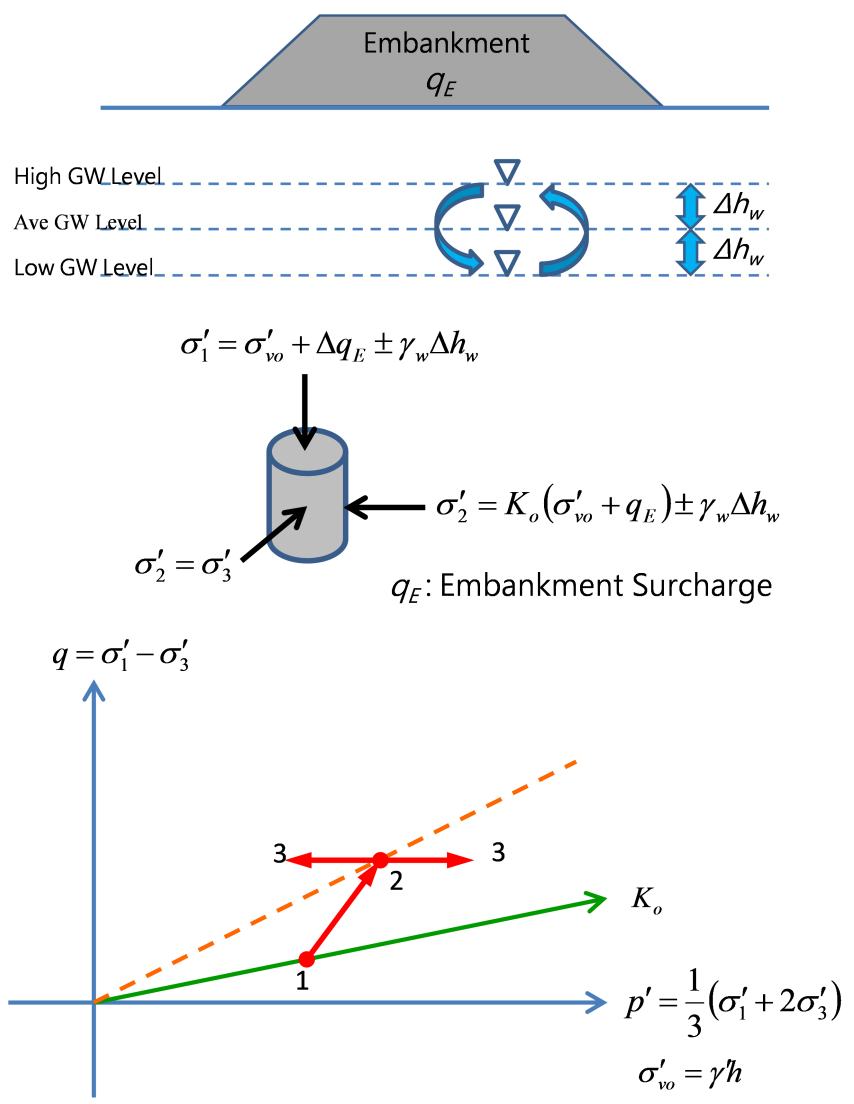

Stage 1 : Before Embankment Construction

Stage 2 : Construction Complete

Stage 3 : Ground Water Fluctuation

Figure 5. Stress path on $\mathrm{P}^{\prime}$-q space for loadings of combined effect.

\section{Stress path of the loading for combined effect}

Figure 5 is the stress path on $\mathrm{P}^{\prime}$-q space considering surcharge load from embankment and groundwater fluctuation It demonstrates the stress path of soil layers in three stages, namely prior to embankment construction (stage 1), embankment construction complete (stage 2), and ground subject to the existing embankment with seasonal ground water level fluctuation (stage 3). Within the aquifer, the principle effective sstress $\sigma_{1}^{\prime}, \sigma_{\mathrm{vo}}^{\prime}+q_{\mathrm{E}} \pm \gamma_{\mathrm{w}} \Delta h_{\mathrm{w}}$, changes with cyclic groundwater lowering. Combined with the surcharge loading increment $q_{E}$, there arises a zone with effective stress $\sigma_{\mathrm{vo}}^{\prime}+\Delta q_{\mathrm{E}} \pm \gamma_{\mathrm{w}} \Delta h_{\mathrm{w}}$. In the dry season, while the groundwater level is relatively low, the combined effective stress $\sigma_{\mathrm{vo}}^{\prime}+\Delta q_{\mathrm{E}}$ increases by $\gamma_{\mathrm{w}} \Delta h_{\mathrm{w}}$, and it decreases by the same amount in the wet season. Hence, within the zone of combined effects, the ground may settle more in the dry season and heave less in the wet season compared to natural ground without the surcharge effect. For soils at greater depth, where $q_{\mathrm{E}}$ is low, the soil heave in the wet season may be limited by the thick overburden. For soils at shallow depth, where 
$q_{\mathrm{E}}$ is relatively high, ground settlement/upheaval will be predominantly governed by $q_{\mathrm{E}}$. Yang et al. (2013) reported that at this site, fluctuation of ground movements was only observed in the second aquifer, particularly in the sand and silt layers. For soils below $230 \mathrm{~m}$, the monitored settlement-time curve was smooth with little fluctuation, indicating that very limited soil heave occurred at this depth. Xi et al. (2012) recently performed a series of laboratory model tests to study the deformation characteristics of remolded silt specimens under the coupling effect of cyclic groundwater fluctuation and footing pressure. Larger settlement occurred when the groundwater was in the lowering stage with lighter footing pressure.

Based on the studies above, pier settlement of pier P5 is outside of the affected zone and free from the combined effect. On the other hand, the pier P3 and P2 is under the influence of surcharge loading from the embankment. The settlement difference between P3 and P5 should be resulted from the loading combined effects.

\section{Conclusions}

The study of this complicated problem is still on-going, and further measurements of ground settlement and pier settlement together with groundwater level changes at the site are being performed. Thus far, the following tentative conclusions can be derived from this study.
The regional ground subsidence occurred below the pile tip has changed the vertical alignment and elevation of the viaduct structure. Only the portion of ground subsidence contributed by soil compression above the pile tip could affect the performance of pile structure due to relative movement and possible negative skin friction on the working piles.

A combined effect occurred under the embankment surcharge and groundwater fluctuation and lowering is deemed to have increased the relative movement between ground and working pile structure.

The study demonstrates that a total of $12.4 \mathrm{~cm}$ settlement on piles for pier P3 during the period from 2003 to 2011 due to the combined effect from embankment surcharge and ground water fluctuation.

\section{References}

Yang, H. W. and Hseih, J.: Engineering Assessment of Ground Subsidence to Railway Infrastructure, Proc. of 7th International Symposium of Land Subsidence, Shanghai, China, 2007.

Yang, H. W., Kao, T., Yu, C., Ho, S. K., and Woo, S. M.: Settlement Behaviours of Structure and Fluctuation of Ground Water in Ground Subsidence Area, Proc. of 15th Conf. on Current Research in Geotechnical Engineering in Taiwan, 2013.

Xi, Y., Xuewen, L., Qingshan, M., and Yue, Q.: Test Study on Deformation Characteristics of Silt - Soil Foundation under Condition of Groundwater Fluctuation, Yangtze River, 43, 84-87, 2012. 